The Agriculturists 16(2): 93-101(2018) ISSN 2304-7321 (Online), ISSN 1729-5211 (Print)

A Scientific Journal of Krishi Foundation

Indexed Journal

DOI: http://dx.doi.org/ 10.3329/agric.v16i02.40347

Impact Factor: 0.568 (GIF, 2015)

\title{
Impact of Rice Husk Biochar on Growth, Water Relations and Yield of Maize (Zea mays L.) under Drought Condition
}

\author{
M. A. Shashi ${ }^{1}$, M. A. Mannan ${ }^{1}$, M. M. Islam ${ }^{1}$ and M. M. Rahman ${ }^{2}$ \\ ${ }^{1}$ Department of Agronomy and ${ }^{2}$ Department of Soil Science \\ Bangabandhu Sheikh Mujibur Rahman Agricultural University, Gazipur-1706, Bangladesh \\ *Corresponding author and Email: mannanbsmrau@yahoo.com
}

Received: 23 October 2018

Accepted: 25 December 2018

\begin{abstract}
The present experiment was conducted to study the impact of rice husk biochar on growth, water relations and yield of maize (BARI Hybrid Bhutta- 9) under drought (60 and $40 \%$ of FC) conditions. Four doses of rice husk biochar @ 0, 5, 10 and 20 t/ha were applied as an amendment in soil before sowing of seeds. Results revealed that drought stress reduced plant height, relative water content and grain yield of maize. But rice husk biochar at different doses improved the above mentioned characters under drought conditions. Under $60 \%$ of FC, the highest plan height, leaf water content and yield were $196.67 \mathrm{~cm}, 79.86 \%$ and $89.75 \mathrm{~g} /$ plant, respectively when biochar was applied @ $20 \mathrm{t} / \mathrm{ha}$ but it was $173.33 \mathrm{~cm}, 78.32 \%$ and $84.57 \mathrm{~g} /$ plant, respectively under $40 \%$ of FC when biochar was applied at the same dose. It may be concluded that, rice husk biochar @ $20 \mathrm{t} / \mathrm{ha}$ showed the best result to promote growth, water relation traits and yield of maize under drought condition.
\end{abstract}

Keywords: Rice husk biochar, growth, yield, maize, drought.

\section{Introduction}

Maize (Zea mays L.) is the third most important cereal crop in Bangladesh, after rice and wheat. It can be cultivated year round. The crop is high yielding, rich in nutrient and has diversified uses. The demand of maize in Bangladesh is primarily from the commercial feed processing industry especially poultry sector is using $80 \%$ of its aggregate maize production (excluding imports) (WPSA, 2013). Therefore, production of maize needs to be increased. Growth and yield of maize are severely affected by drought (WPSA, 2013) in winter season where rainfall is low. Water absorption, imbibition and metabolic enzymatic activation are hindered under drought condition which reduces the grain germination. Drought stress inhibits the photosynthesis of plants, causes changes of chlorophyll contents and damages the photosynthetic apparatus (Escuredo et al., 1998) which ultimately reduce growth promoters (Praba et al., 2009). Under drought stress, cell expansion of leaf is reduced due to low turgor which is controlled by the processes related to cellular water uptake and cell wall extension that resulted in decreased leaf area and weight. The yield and biochemical composition of a plant mainly depends on growth conditions, which is markedly affected by water availability (Paclik et al., 1996).

Biochar is charcoal formed from the thermal decomposition of biomass in a low or zero oxygen environment, at high temperatures 
$\left(<700^{\circ} \mathrm{C}\right)$ (Lehmann and Joseph, 2009), intended for use as a soil amendment (Lehmann and Joseph, 2009), enhanced soil water-holding capacity (Asai et al., 2009; Laird et al., 2009; Karhu and Matilla, 2011), improved soil water permeability and improved saturated hydraulic conductivity (SHC) (Asai et al., 2009), reduced soil strength (Chan et al., 2007), modification in soil bulk density $(\rho b)$ and modified aggregate stability (Busscher et al., 2010; Peng et al., 2011). Biochar improves crop productivity and mitigates drought (Thomas et al., 2013; Crane et al., 2013), has the potential to increase the availability of plants nutrient (Lehmann et al., 2008) and increases growth and biomass of drought-stressed plants reported by Rizwan et al. (2017).

Therefore the experiment was undertaken to assess the effects of rice husk biochar on growth, water relations and yield of maize variety BARI Hybrid Bhutta-9 under drought conditions.

\section{Materials and Methods}

\subsection{Location of the experiment}

The pot experiment was conducted in the Department of Agronomy, Bangabandhu Sheikh Mujibur Rahman Agricultural University (BSMRAU), Gazipur from November 2016 to March 2017.

\subsection{Experimental soil characteristics}

The soil used in the experiment was sandy loam in texture, organic carbon contain $0.60 \%$, total $\mathrm{N} \quad 0.05 \%$, available $\mathrm{P} \quad 0.08 \mathrm{mg} / 100 \mathrm{~g}$, exchangeable $\mathrm{K} 0.33 \mathrm{cmol}_{\mathrm{c}} \mathrm{kg}^{-1}$ and CEC 14.58 $\mathrm{cmol}_{\mathrm{c}} \mathrm{kg}^{-1}$ dry soil and the $\mathrm{pH}$ was 7.1.

\subsection{Biochar characteristics}

Biochar was produced from rice husk by pyrolysis in biochar stove developed by Mia et al. (2015) and modified by Mannan et al. (2016). The chemical properties of rice husk biochar were N $2.57 \%$, P $0.21 \%$, K $0.231 \%$, Ca $1.024 \%$, $\mathrm{Mg} 0.458 \%$, S $0.339 \%$, EC $1.325 \mathrm{mS} / \mathrm{cm}$ and $7.15 \mathrm{pH}$ was recorded.

\subsection{Fertilizers application}

The soil in the pot was fertilized uniformly with 2.0, 1.15 and $0.9 \mathrm{~g}$ urea, triple super phosphate and muriate of potash corresponding to 525-250 $200 \mathrm{~kg}$ urea, triple super phosphate and muriate of potash per hectare, respectively (BARC, 2012).

\subsection{Treatments}

a) Biochar doses: Rice husk biochar was mixed uniformly in the soil of each pot with 24.4, 48.8 , and $97.6 \mathrm{~g}$ corresponding to at the rate of 5,10 and $20 \mathrm{t} / \mathrm{ha}$, respectively and biochar was not applied to control plot.

b) Drought: Three water regimes i) Control ( $80 \%$ of field capacity), ii) $60 \%$ of field capacity (FC) and iii) $40 \%$ of field capacity (FC) were maintained from $4^{\text {th }}$ leaf stage of seedling up to maturity.

\subsection{Crop establishment and drought imposition} Ten bold seeds of BARI Hybrid Bhutta- 9 were sown in each plastic pot containing about $11 \mathrm{~kg}$ air dried soil. After seven days of germination, two uniform and healthy plants were allowed to grow in each pot. Drought stress was induced by withholding water completely. During the drought treatment period, wilting symptom was visually observed every day. The pots were weighed every other day to compensate the water loss by evapotranspiration according to Choudhury et al. (2014). In non-stress treatment, one liter water per pot was applied in alternate day up to maturity.

\subsection{Experimental design and data recorded}

The experiment was designed at Completely Randomized (CRD) consisting two factors with three replications. The data on plant height were recorded at vegetative $\left(6^{\text {th }}\right.$ leaf, $10^{\text {th }}$ leaf, $14^{\text {th }}$ leaf) and reproductive (tasselling, cob initiation and maturation stage) stages. Water relation traits (relative water content, water saturation deficit, water uptake capacity) of maize leaf were recorded at flowering stage. Yield and yield contributing parameters were recorded at maturity after harvest. The recorded data were 
statistically analyzed by "CropStat" (IRRI, 2007) software to examine the significant variation of the results due to water stress. The treatment means were compared by Least Significance Difference (LSD) test at $5 \%$ level of significance (Gomez \& Gomez, 1984).

\section{Results and Discussion}

\subsection{Plant height at vegetative stage}

The height of maize at vegetative stage varied due to different doses of biochar under drought conditions (Table 1). At $6^{\text {th }}$ leaf stage, plant height was reduced due to drought and higher reduction was found at $40 \%$ of FC compare to the $60 \%$ of FC. But applications of biochar increased plant height under both of these drought conditions. Highest plant height (43.80 cm) was measured when biochar was applied @ $20 \mathrm{t} / \mathrm{ha}$ and it was $42.03 \mathrm{~cm}$ at $40 \%$ of $\mathrm{FC}$ at same dose of biochar. At $10^{\text {th }}$ leaf stage, under control condition plant height was measured $95.43 \mathrm{~cm}$ when biochar was applied @ 20 t/ha but the plant height was $90.40 \mathrm{~cm}$ when no biochar was applied. At $60 \%$ of field capacity and $40 \%$ of field capacity higher height of maize were $93.00 \mathrm{~cm}$ and $91.20 \mathrm{~cm}$, respectively when biochar was applied @ 20 t/ha. At $14^{\text {th }}$ leaf stage, under control condition shortest plant (150.60 $\mathrm{cm})$ was obtained when no biochar was applied, on the other hand it was highest $(169.33 \mathrm{~cm})$ when biochar was applied @ 20 t/ha. Under 60\% of field capacity and $40 \%$ of field capacity longer plant were $154.33 \mathrm{~cm}$ and $145.00 \mathrm{~cm}$, respectively when biochar was applied @ 20 t/ha.

Table 1. Effect of rice husk biochar on plant height of maize at vegetative stages under drought conditions

\begin{tabular}{|c|c|c|c|c|c|c|c|c|c|}
\hline \multirow{2}{*}{$\begin{array}{c}\text { Biochar } \\
\text { doses } \\
\text { (t/ha) }\end{array}$} & \multicolumn{3}{|c|}{$6^{\text {th }}$ leaf stage $(\mathrm{cm})$} & \multicolumn{3}{|c|}{ 10th leaf stage $(\mathrm{cm})$} & \multicolumn{3}{|c|}{ 14th leaf stage $(\mathrm{cm})$} \\
\hline & control & $\begin{array}{l}60 \% \\
\text { of FC }\end{array}$ & $\begin{array}{c}40 \% \\
\text { of FC }\end{array}$ & control & $\begin{array}{c}60 \% \\
\text { of FC }\end{array}$ & $\begin{array}{l}40 \% \\
\text { of FC }\end{array}$ & control & $\begin{array}{l}60 \% \\
\text { of FC }\end{array}$ & $\begin{array}{l}40 \% \\
\text { of FC }\end{array}$ \\
\hline 0 & $39.36 \mathrm{de}$ & $39.13 \mathrm{e}$ & $38.70 \mathrm{f}$ & $90.40 \mathrm{~b}$ & $89.50 \mathrm{~b}$ & $80.23 \mathrm{~b}$ & $150.60 \mathrm{~d}$ & $139.00 \mathrm{f}$ & $134.33 \mathrm{f}$ \\
\hline 5 & 42.16 a-e & 40.96b-e & $40.16 \mathrm{cde}$ & $91.23 \mathrm{ab}$ & $90.43 \mathrm{~b}$ & $90.26 \mathrm{~b}$ & $156.66 \mathrm{c}$ & $145.33 \mathrm{e}$ & $136.33 \mathrm{f}$ \\
\hline 10 & $42.80 \mathrm{abc}$ & 41.90 a-e & 41.16b-e & $93.93 \mathrm{ab}$ & $91.43 \mathrm{ab}$ & $90.70 \mathrm{~b}$ & $164.00 \mathrm{~b}$ & $151.33 \mathrm{~d}$ & $138.33 \mathrm{f}$ \\
\hline 20 & $44.83 \mathrm{a}$ & $43.80 \mathrm{ab}$ & $42.03 \mathrm{a}-\mathrm{e}$ & $95.43 \mathrm{a}$ & $93.00 \mathrm{ab}$ & $91.20 \mathrm{ab}$ & $169.33 \mathrm{a}$ & $154.33 \mathrm{~cd}$ & $145.00 \mathrm{e}$ \\
\hline $\mathrm{CV}(\%)$ & & 4.2 & & & 3.1 & & & 2.0 & \\
\hline
\end{tabular}

In a column, figures with same letters were not significant at $5 \%$ level.

Table 2. Effect of rice husk biochar on plant height in maize at reproductive stages under drought conditions

\begin{tabular}{|c|c|c|c|c|c|c|c|c|c|}
\hline \multirow{2}{*}{$\begin{array}{c}\text { Biochar } \\
\text { doses } \\
\text { (t/ha) }\end{array}$} & \multicolumn{3}{|c|}{ Tasseling stage $(\mathrm{cm})$} & \multicolumn{3}{|c|}{ Cob initiation stage $(\mathrm{cm})$} & \multicolumn{3}{|c|}{ Maturity stage $(\mathrm{cm})$} \\
\hline & control & $\begin{array}{l}60 \% \\
\text { of FC }\end{array}$ & $\begin{array}{l}40 \% \\
\text { of FC }\end{array}$ & control & $\begin{array}{l}60 \% \\
\text { of FC }\end{array}$ & $\begin{array}{l}40 \% \\
\text { of FC }\end{array}$ & control & $\begin{array}{l}60 \% \\
\text { of FC }\end{array}$ & $\begin{array}{l}40 \% \\
\text { of FC }\end{array}$ \\
\hline 0 & $164.00 \mathrm{~cd}$ & $161.67 \mathrm{~d}$ & $136.67 \mathrm{f}$ & $174.33 \mathrm{~cd}$ & $170.00 \mathrm{~d}$ & $141.33 \mathrm{f}$ & $175.33 \mathrm{c}$ & $173.00 \mathrm{c}$ & $154.00 \mathrm{e}$ \\
\hline 5 & $172.67 \mathrm{bc}$ & $172.00 \mathrm{bc}$ & $139.33 \mathrm{f}$ & $175.67 \mathrm{~cd}$ & $174.67 \mathrm{~cd}$ & $145.33 \mathrm{f}$ & $180.67 b c$ & $178.33 \mathrm{bc}$ & $156.67 \mathrm{de}$ \\
\hline 10 & $174.33 \mathrm{~b}$ & $174.00 \mathrm{~b}$ & $151.33 \mathrm{e}$ & $186.67 \mathrm{~b}$ & $182.67 \mathrm{bc}$ & $157.67 \mathrm{e}$ & $186.67 \mathrm{~b}$ & $185.67 \mathrm{~b}$ & $163.00 \mathrm{~d}$ \\
\hline 20 & $190.00 \mathrm{a}$ & $184.33 \mathrm{a}$ & $165.67 \mathrm{bcd}$ & $195.67 \mathrm{a}$ & $190.33 \mathrm{ab}$ & $169.00 \mathrm{~d}$ & $202.33 \mathrm{a}$ & $195.67 \mathrm{a}$ & $173.33 \mathrm{c}$ \\
\hline $\mathrm{CV}(\%)$ & & 3.5 & & & 2.9 & & & 2.9 & \\
\hline
\end{tabular}

In a column, figures with same letters were not significant at 5\% level. 
So it is clear that plant height is affected by drought and application of rice husk biochar increase plant height that means biochar mitigate drought effects on plant height. Plant height of maize was reduced due to drought at vegetative stages reported by Abukari (2014). Hussain et al. (2008) reported that by affecting cell turgidity drought impaired plant height. Lehmann et al. (2011) also reported that biochar promoted plant height of maize under drought conditions. Kim et al. (2016) found that application of biochar can increase soil water holding capacity which increased tissue water status and ultimately increased plant height.

\subsection{Plant height at reproductive stage}

Plant height differences of maize at reproductive stages indicated that plant height varied due to different doses of biochar under drought conditions (Table 2). At tasseling stage, under control condition highest plant height was found $190.00 \mathrm{~cm}$ when biochar was applied @ $20 \mathrm{t} / \mathrm{ha}$, followed by $174.33 \mathrm{~cm}$ and $172.67 \mathrm{~cm}$ when biochar was applied $10 \mathrm{t} / \mathrm{ha}$ and $5 \mathrm{t} / \mathrm{ha}$, respectively but the lowest plant height (164.00 $\mathrm{cm}$ ) was measured when no biochar was applied. Drought stress reduced plant height of maize compared to the control and highest reduction was found under $40 \%$ of FC. But biochar increased plant height under drought conditions. At $60 \%$ of field capacity the highest height of maize was $184.33 \mathrm{~cm}$ when biochar was applied @ $20 \mathrm{t} / \mathrm{ha}$ and the shortest plant was $161.67 \mathrm{~cm}$ and when no biochar was applied. At $40 \%$ of field capacity the highest height of maize was $165.67 \mathrm{~cm}$ when biochar was applied @ 20 t/ha and the shortest plant was $136.67 \mathrm{~cm}$ when no biochar was applied. At cob initiation stage, under $60 \%$ of field capacity highest plant height of maize was $190.33 \mathrm{~cm}$ when biochar was applied@20 t/ha, followed by @ 10 t/ha biochar $(182.67 \mathrm{~cm})$, @ 5 t/ha biochar $(174.67$ $\mathrm{cm})$ and lowest plant height $(170.00 \mathrm{~cm})$ of maize was found when no biochar was applied. Under $40 \%$ of FC same trend also found in case of height of maize plant. At maturity stage, under control condition highest plant height of maize was $202.33 \mathrm{~cm}$ when biochar was applied @ 20 t/ha and the shortest plant was observed in no biochar treatment. At $60 \%$ of field capacity highest plant height of maize was $195.67 \mathrm{~cm}$ when biochar was applied @ 20 t/ha, followed by @ 10 t/ha biochar $(185.67 \mathrm{~cm})$, @ 5 t/ha biochar $(178.33 \mathrm{~cm})$ and lowest plant height $(173.00 \mathrm{~cm})$ was found when no biochar was applied. At $40 \%$ of field capacity lowest plant height of maize was $154.00 \mathrm{~cm}$ when no biochar was applied. But application of biochar plant height was increased. The highest plant height $(173.33 \mathrm{~cm})$ was recorded at the rate of $20 \mathrm{t} / \mathrm{ha}$ biochar application followed by $163.00 \mathrm{~cm}$ for $10 \mathrm{t} / \mathrm{ha}$ and $156.67 \mathrm{~cm}$ for $5 \mathrm{t} / \mathrm{ha}$. It was found that drought stress affected plant height at reproductive stages and biochar application in soil increased plant height under drought conditions. Drought induced plant height reduction was reported by Batool et al. (2015) in maize. Hardy et al. (2014) also reported that the addition of biochar improved plant height. In rice, drought stress during the vegetative stage greatly reduced the plant height (Manikavelu et al., 2006).

\subsection{Water relation traits}

Relative Water Content (RWC) of maize plant was reduced significantly under drought stress. Application of rice husk biochar at different doses increased water holding capacity of soil under drought conditions and thereby increased relative water content (RWC) of maize leaves (Table 3). Under control condition, $60 \%$ and $40 \%$ of field capacity the highest RWC of maize were $83.37 \%, 79.86 \%$ and $78.32 \%$, respectively when biochar was applied @20 t/ha. The lowest RWC of maize were $66.93 \%, 63.75 \%$ and $62.25 \%$, respectively when no biochar was applied. Water saturation deficit (WSD) of maize plant was increased significantly under drought stress and varied due to application of biochar with different doses (Table 3). Under control condition, the lowest WSD of maize leaf was $16.62 \%$, when biochar was applied @ 20 t/ha and highest WSD of maize leaf was $33.06 \%$, when no biochar was applied. At $60 \%$ of field capacity highest water saturation deficit of maize leaf was $36.24 \%$ when no biochar was applied 
but lowest water saturation deficit $(20.13 \%)$ was found when biochar was applied @ 20 t/ha. At $40 \%$ of field capacity lowest water saturation deficit was $21.17 \%$ when biochar was applied @ $20 \mathrm{t} / \mathrm{ha}$. On the other hand highest water saturation deficit was $37.74 \%$ when no biochar was applied. Water uptake capacity (WUC) of maize was increased significantly under drought conditions but application of biochar decreased water uptake capacity (Table 3).At control condition the lowest WUC of maize was 1.52, when biochar was applied @20 t/ha and highest WUC of maize leaf was 1.90 , when no biochar was applied. At $60 \%$ of field capacity highest water uptake capacity was 1.97 when no biochar was applied but lowest water uptake capacity was 1.55 when biochar was applied @ 20 t/ha.
At $40 \%$ of field capacity lowest water uptake capacity was 1.61 when biochar was applied @ $20 \mathrm{t} / \mathrm{ha}$ but the highest water uptake capacity was 2.02 when no biochar was applied. Akhtar et al. (2014) found that biochar increased RWC and water use efficiency of drought stressed tomato plants. Uzoma et al. (2011) also reported that biochar increased water status of maize tissue in sandy soil.

\subsection{Reproductive growth of maize}

The number of cob was 1.0 per plant which did not varied with drought levels and treatments (Table 4). Drought stress affected length of cob. When biochar was applied at different doses the cob length was gradually increased (Table 4).

Table 3. Effect of rice husk biochar on relative water content, water saturation deficit and water uptake capacity of maize under drought conditions

\begin{tabular}{cccccccccc}
\hline $\begin{array}{c}\text { Biochar } \\
\text { doses } \\
(\mathrm{t} / \mathrm{ha})\end{array}$ & \multicolumn{3}{c}{ Relative water content (\%) } & \multicolumn{3}{c}{ Water saturation deficit (\%) } & \multicolumn{3}{c}{ Water uptake capacity } \\
\cline { 2 - 9 } & control & $\begin{array}{c}60 \% \\
\text { of FC }\end{array}$ & $\begin{array}{c}40 \% \\
\text { of FC }\end{array}$ & control & $\begin{array}{c}60 \% \\
\text { of FC }\end{array}$ & $\begin{array}{c}40 \% \\
\text { of FC }\end{array}$ & control & $\begin{array}{c}60 \% \\
\text { of FC }\end{array}$ & $\begin{array}{c}40 \% \\
\text { of FC }\end{array}$ \\
\hline 0 & $66.93 \mathrm{abc}$ & $63.75 \mathrm{bc}$ & $62.25 \mathrm{c}$ & $33.06 \mathrm{abc}$ & $36.24 \mathrm{ab}$ & $37.74 \mathrm{a}$ & $1.90 \mathrm{ab}$ & $1.97 \mathrm{a}$ & $2.02 \mathrm{a}$ \\
5 & $71.17 \mathrm{abc}$ & $70.20 \mathrm{abc}$ & $66.42 \mathrm{abc}$ & $28.83 \mathrm{abc}$ & $29.79 \mathrm{abc}$ & $33.58 \mathrm{abc}$ & $1.81 \mathrm{a}-\mathrm{d}$ & $1.83 \mathrm{abc}$ & $1.98 \mathrm{a}$ \\
10 & $76.87 \mathrm{abc}$ & $75.78 \mathrm{abc}$ & $72.82 \mathrm{abc}$ & $23.13 \mathrm{abc}$ & $24.31 \mathrm{abc}$ & $27.18 \mathrm{abc}$ & $1.71 \mathrm{a}-\mathrm{d}$ & $1.79 \mathrm{a}-\mathrm{d}$ & $1.82 \mathrm{a}-\mathrm{d}$ \\
20 & $83.37 \mathrm{a}$ & $79.86 \mathrm{ab}$ & $78.32 \mathrm{abc}$ & $16.62 \mathrm{c}$ & $20.13 \mathrm{bc}$ & $21.17 \mathrm{abc}$ & $1.52 \mathrm{~d}$ & $1.55 \mathrm{~cd}$ & $1.61 \mathrm{bcd}$ \\
\hline $\mathrm{CV}(\%)$ & \multicolumn{3}{c}{14.1} & & & 36.8 & & & 10.7 \\
\hline
\end{tabular}

In a column, figures with same letters were not significant at $5 \%$ level..

Table 4. Effect of rice husk biochar on reproductive growth of maize under drought conditions

\begin{tabular}{cccccccccc}
\hline $\begin{array}{c}\text { Biochar } \\
\text { doses } \\
(\mathrm{t} / \mathrm{ha})\end{array}$ & \multicolumn{3}{c}{ Number of cob } & \multicolumn{3}{c}{ Length of cob $(\mathrm{cm})$} & \multicolumn{3}{c}{ Diameter of cob $(\mathrm{cm})$} \\
\cline { 2 - 9 } & control & $\begin{array}{c}60 \% \\
\text { of FC }\end{array}$ & $\begin{array}{c}40 \% \\
\text { of FC }\end{array}$ & control & $\begin{array}{c}60 \% \\
\text { of FC }\end{array}$ & $\begin{array}{c}40 \% \\
\text { of FC }\end{array}$ & control & $\begin{array}{c}60 \% \\
\text { of FC }\end{array}$ & $\begin{array}{c}40 \% \text { of } \\
\text { FC }\end{array}$ \\
\hline 0 & $1.0 \mathrm{a}$ & $1.0 \mathrm{a}$ & $1.0 \mathrm{a}$ & $15.93 \mathrm{abc}$ & $13.23 \mathrm{bc}$ & $12.10 \mathrm{c}$ & $3.50 \mathrm{abc}$ & $3.20 \mathrm{c}$ & $3.15 \mathrm{c}$ \\
5 & $1.0 \mathrm{a}$ & $1.0 \mathrm{a}$ & $1.0 \mathrm{a}$ & $16.53 \mathrm{ab}$ & $14.73 \mathrm{abc}$ & $14.63 \mathrm{abc}$ & $3.60 \mathrm{abc}$ & $3.35 \mathrm{bc}$ & $3.25 \mathrm{c}$ \\
10 & $1.0 \mathrm{a}$ & $1.0 \mathrm{a}$ & $1.0 \mathrm{a}$ & $17.23 \mathrm{ab}$ & $15.13 \mathrm{abc}$ & $15.03 \mathrm{abc}$ & $3.83 \mathrm{ab}$ & $3.50 \mathrm{abc}$ & $3.35 \mathrm{abc}$ \\
20 & $1.0 \mathrm{a}$ & $1.0 \mathrm{a}$ & $1.0 \mathrm{a}$ & $17.66 \mathrm{a}$ & $15.33 \mathrm{abc}$ & $15.30 \mathrm{abc}$ & $3.90 \mathrm{a}$ & $3.65 \mathrm{abc}$ & $3.50 \mathrm{abc}$ \\
\hline $\mathrm{CV}(\%)$ & & 0.0 & & & 15.7 & & & 2.15 \\
\hline
\end{tabular}

In a column, figures with same letters were not significant at $5 \%$ level. 
Under control condition the highest length of cob $(17.66 \mathrm{~cm})$ was found at $20 \mathrm{t} / \mathrm{ha}$ of biochar treatment and the lowest one $(15.93 \mathrm{~cm})$ was for control (no biochar). Under $60 \%$ of field capacity the highest length of cob was $15.33 \mathrm{~cm}$ at $20 \mathrm{t} / \mathrm{ha}$ of biochar and the lowest $13.23 \mathrm{~cm}$ was for control. Under $40 \%$ of field capacity the highest length of cob was $15.30 \mathrm{~cm}$ with was applied @ 20 t/ha of biochar and the lowest $(12.10 \mathrm{~cm})$ was for control. Cob diameter of maize reduced under drought stress. The highest reduction was for $40 \%$ of field capacity compare to that for $60 \%$ of FC but application of biochar increased diameter of cobs (Table 4). Under control condition highest cob diameter $(3.90 \mathrm{~cm})$ was found when biochar was applied @ 20 t/ha and it was lowest $(3.50 \mathrm{~cm})$ when no biochar was applied. Under $60 \%$ of field capacity highest cob diameter $(3.65 \mathrm{~cm})$ was found when biochar was applied @ $20 \mathrm{t} / \mathrm{ha}$ and it was lowest $(3.20 \mathrm{~cm})$ when no biochar was applied. Under $40 \%$ of field capacity highest cob diameter $(3.50 \mathrm{~cm})$ was found when biochar was applied @ 20 t/ha and it was lowest $(3.15 \mathrm{~cm})$ when no biochar was applied.

\subsection{Yield and yield contributing characters}

Number of seed per cob, 100 grain weight and grain yield varied significantly with biochar doses under drought conditions (Table 5). Under control condition highest number of seed per cob was 353.00 when biochar was applied @ 20 t/ha and lowest number of seed per cob was 163.00 when no biochar was applied. At $60 \%$ of FC highest number of seed per cob was 335.00 when biochar was applied @ 20 t/ha and lowest number os seed per cob was 147.33 when no biochar was applied. Under $40 \%$ of FC highest number of seed per cob was 334.66 when biochar was applied @ 20 t/ha and lowest number of seed per cob was 139.00 when no biochar was applied. Under control condition highest 100 grain weight $(27.74 \mathrm{~g})$ was found when biochar was applied @ 20 t/ha and it was lowest $(21.88 \mathrm{~g})$ when no biochar was applied. Under $60 \%$ of field capacity highest 100 grain weight $(26.51 \mathrm{~g})$ was found when biochar was applied @ 20 t/ha and it was lowest (20.71 g) when no biochar was applied. At $40 \%$ of field capacity highest 100 grain weight $(25.00 \mathrm{~g})$ was found when biochar was applied @ 20 t/ha and it was lowest $(20.00 \mathrm{~g})$ when no biochar was applied. Grain yield reduced due to drought but application of biochar maize grain yield increased (Table 5). Under control condition highest grain yield was $96.70 \mathrm{~g} /$ plant when biocharwas applied @ 20 t/ha and lowest grain yield was $40.71 \mathrm{~g} / \mathrm{plant}$, when no biochar was applied. At $60 \%$ of FC the highest grain yield was $89.78 \mathrm{~g} /$ plant when biochar was applied @ $20 \mathrm{t} / \mathrm{ha}$ and lowest grain yield was $35.92 \mathrm{~g} / \mathrm{plant}$ when no biochar was applied. Under $40 \%$ of FC the highest grain yield was $84.57 \mathrm{~g} /$ plant when biocharwas applied @ 20 t/ha and lowest grain yield was $27.84 \mathrm{~g} /$ plant when no biochar was applied.

Table 5. Effect of rice husk biochar on number of seed/cob, 100 grain wt. (g) and grain yield (g) of maize under drought conditions

\begin{tabular}{|c|c|c|c|c|c|c|c|c|c|}
\hline \multirow{2}{*}{$\begin{array}{c}\text { Biochar } \\
\text { doses } \\
\text { (t/ha) }\end{array}$} & \multicolumn{3}{|c|}{ Number of seed /cob } & \multicolumn{3}{|c|}{100 grain weight $(\mathrm{g})$} & \multicolumn{3}{|c|}{ Grain yield (g/plant) } \\
\hline & control & $\begin{array}{l}60 \% \\
\text { of FC }\end{array}$ & $\begin{array}{l}40 \% \\
\text { of FC }\end{array}$ & control & $\begin{array}{l}60 \% \\
\text { of FC }\end{array}$ & $\begin{array}{l}40 \% \\
\text { of FC }\end{array}$ & control & $\begin{array}{l}60 \% \\
\text { of FC }\end{array}$ & $\begin{array}{l}40 \% \\
\text { of FC }\end{array}$ \\
\hline 0 & $163.00 \mathrm{bcd}$ & $147.33 \mathrm{~cd}$ & $139.00 \mathrm{~d}$ & $21.88 \mathrm{abc}$ & $20.71 \mathrm{bc}$ & $20.00 \mathrm{c}$ & $40.71 \mathrm{~cd}$ & $35.92 \mathrm{~cd}$ & $27.84 \mathrm{~d}$ \\
\hline 5 & $273.00 \mathrm{a}-\mathrm{d}$ & $244.00 \mathrm{a}-\mathrm{d}$ & $164.33 \mathrm{bcd}$ & $23.48 \mathrm{abc}$ & $21.73 \mathrm{abc}$ & $21.40 \mathrm{abc}$ & $58.61 \mathrm{a}-\mathrm{d}$ & $57.54 a-d$ & $34.97 \mathrm{~cd}$ \\
\hline 10 & $300.00 \mathrm{ab}$ & $297.00 \mathrm{abc}$ & $288.33 a-d$ & $26.88 \mathrm{ab}$ & $23.07 \mathrm{abc}$ & $21.53 \mathrm{abc}$ & $79.59 \mathrm{ab}$ & 68.92abc & $61.09 a-d$ \\
\hline 20 & $353.00 \mathrm{a}$ & $335.00 \mathrm{a}$ & $334.66 \mathrm{a}$ & $27.74 \mathrm{a}$ & $26.51 \mathrm{abc}$ & $25.00 \mathrm{abc}$ & $96.70 \mathrm{a}$ & $89.78 \mathrm{ab}$ & $84.57 \mathrm{ab}$ \\
\hline $\mathrm{CV}(\%)$ & & 35.5 & & & 16.70 & & & 37.40 & \\
\hline
\end{tabular}

In a column, figures with same letters were not significant at $5 \%$ level. 
Estrada-Campuzano et al. (2008) observed that water stress reduced yield of triticale and reductions of yield have been reported in snap bean by Lakitan et al. (1992). Drought stress affect negatively on anthesis, grain filling of maize associated with reduction of number seed/cob, 100 grain weight and ultimately grain yield. Decrease of photosynthesis under drought conditions also affected grain yield. Drought stress affect negatively on anthesis, grain filling of maize associated with reduction of number seed/cob, 100 grain weight and ultimately grain yield. Increasing of cassava yield with biochar application has been shown by Islami et al (2011) and Mannan et al. (2016) reported that biochar increased pod yield of soybean under saline stress. Foster et al. (2016) observed biochar application increased maize yield semi arid conditions. Application of biochar increased photosynthesis efficiency, anthesis and grain filling thereby increased yield of maize.

\section{Conclusions}

From the obtained results it might be concluded that application of rice husk biochar had positive impact on growth, water relation traits and yield of maize under drought conditions. Among the doses of rice husk biochar, the rate of $20 \mathrm{t} / \mathrm{ha}$ dose presented the best performance to enhance plant height, leaf water content and yield of maize. So rice husk biochar might be used as a soil amendment to mitigate drought effects in maize.

\section{Acknowledgement}

We are grateful to University Grants Commission (UGC), Bangladesh for funding the research.

\section{References}

Abukari A. 2014. Effect of rice husk biochar on maize productivity in the guinea savannah zone of Ghana. Doctoral dissertation. Department of Agroforestry, Kwame Nkrumah University of Science and Technology.
Akhtar, S. S., Li, G., Andersen M. N., Liu. F. 2014. Biochar enhances yield and quality of tomato under reduced irrigation. Agriculture Water Management. 138: 3744.

Asai H., Samson BK., Stephan HM, Songyikhangsuthor K., Homma K., Kiyono Y., Inoue Y., Shiraiwa T., Horie T.2009. Biochar amendment techniques for upland rice production in Northern Laos 1, Soil physical properties, leaf SPAD and grain yield. Field Crop Research, 111(1): 81-84.

BARC. 2012. Fertilizer Recommendation Guide, Bangladesh Agricultural Research Council, Farmgate, Dhaka.

Batool A., Taj S., Rashid A., Khalid A., Qadeer S., Ghufran MA. 2015. Potential of soil amendments (biochar and gypsum) in increasing water use efficiency of Abelmoschus esculentus L. Moench. Front. Plant Science, 6: 1-13.

Chan KY., Van Zwieten L., Meszaros I., Downie A. Joseph S. 2007. Agronomic values of green waste biochar as a soil amendment. Soil Research. 45(8): 629634.

Choudhury AK., Karim MA., Haque MM., Khaliq QA., Ahmed JU., Hossain MM. 2014. Leaf water status and its relationship with reproductive responses of common bean (Phaseolus vulgaris L.) genotypes under water stress. American Journal of Plant Science, 5: 1547-1556.

Crane-Droesch A., Abiven S., Jeffery S., Torn MS. 2013. Heterogeneous global crop yield response to biochar: a metaregression analysis. Environmental Research Letters, 8(4): 44-49.

Escured IP., Arrese-Igor C., Becana M. 1998. Oxidative damage in pea plants exposed to water deficit or paraquat. Plant Physiol, 116: 173-181.

Estrada-Campuzano, G., Miralles DJ., Slafer GA. 2008. Genotypic variability and 
response to water stress of pre- and postanthesis phases in triticale. European Journal of Agronomy, 28: 171-177.

Foster EJ., Hansen N., Wallenstein M., Cotrufo MF. 2016. Biochar and manure amendments impact soil nutrients and microbial enzymatic activities in a semiarid irrigated maize cropping system. Agriculture Ecosystem and Environment, 233: 404-414.

Gomez KA., Gomez AA. 1984. Statistical procedure of agricultural Research, John Wiley and Sons. Singapore, $21 \mathrm{p}$.

Haider G., Koyro HW., Azam F., Steffens D., Müller C., Kammann C.2015. Biochar but not humic acid product amendment affected maize yields via improving plantsoil moisture relations. Plant Soil, 395: 141-157.

Hardy S., Dunst G., Glaser B. 2014. No effect level of co- composted biochar on plant growth and soil properties in a greenhouse experiment. Agronomy, 4 (1): 34-51.

Hossain MI., Ossain A., Khatun MSA., Talukder MMR., Uddin MS. 2010. Effect of drought on physiology and yield and yield contributing characters of sunflower. Bangladesh Journal of Agricultural Research, 35(1): 113-124.

Hussain M., Malik MA., Farooq M., Ashraf MY., Cheema MA. 2008. Improving drought tolerance by exogenous application of glycinebetaine and salicylic acid in sunflower. Journal of Agronomy and Crop Science, 194: 193-199.

IRRI. 2007. Crop Stat, version 7.2. Biometric unit of International Rice Research Institute, Los Banos, (Philippine).

Islami T., Guritno B., Nurbasuki A., Suryanto A. 2011. Biochar for cassava based cropping system in the degraded lands of East Java, Indonesia. Journal of Tropical Agriculture, 49: 40- 46.
Karhu K., Mattila T., Bergström I., ReginaK. 2011. Biochar addition to agricultural soil increased $\mathrm{CH} 4$ uptake and water holding capacity - Results from a short-term pilot field study. Agriculture, Ecosystems and Environment, 140:309-313.

Kim HS., Kim KR., Yang JE., Ok YS., Owens G., Nehls T., Wessolek G., Kim KH. 2016 .Effect of biochar on reclaimed tidal land soil properties and maize (Zea mays L.) response. Chemosphere, 142: 153-159.

Laird DA., Brown RC, Amonette JE., Lehmann J. 2009. Review of the pyrolysis platform force producing bio-oil and biochar. Bio fuels, Bio products and Bio refining, 3: 547-562.

Lakitan B., Wolfe DB., Zobel RW. 1992. Flooding affects snap bean yield and genotypic variation in leaf gas exchange and root growth response. Journal of American Society Horticultural Science, 117: 711-716.

Lehmann J., Solomon D., Kinyangi J., Dathe L., Wirick S., Jacobsen C. 2008. Spatial complexity of soil organic matter forms at nanometer scales. Nature and Geological Science, 1: 238-242.

Lehmann J., Rillig MC., Thies J., Masiello CA., Hockaday WC., Crowley D. 2011. Biochar effects on soil biota-a review. Soil Biology and Biochemistry, 43: 1812 1836.

Lehmann, JE., Jospeh S. 2009. Characteristics of Biochar: Micro chemical properties, In: J. Lehmann, S. Joseph (eds), Bio-char for Environmental Management Science and Technology, Earthscan, London, 3343pp.

Manikavelu A., Nadarajan N., Ganesh SK., Gnanamalar RP., Babu RC. 2006. Drought tolerance in rice: morphological and molecular genetic consideration. Plant Growth Regulator, 50: 121-138. 
Mannan MA., Halder E., Karim MA., Ahmed JU. 2016. Alleviation of adverse effects of drought stress on soybean (Glycine max L.) by using poultry litter biochar. Bangladesh Agronomy Journal, 19(2): 6169.

Mia S., Abuyusuf M., Sattar MA., Islam ABM., Hiemstraand T., Jeffery S. 2015. Biochar amendment for high nitrogen and phosphorous bio-availability and its potentiality of use in Bangladesh Agriculture: a review. Journal Patuakhali Science and Technology University, 5: 145-156.

Moussa HR. 2011. Low dose of gamma irradiation enhanced drought tolerance in soybean. Bulg. J. Agric. Sci, 17: 63-72.

Paclik R., Sakova L., Curn V. 1996. Reaction of different cultivars of Soybean subsp. oleiferato water stress. FytotechnickaRada, 1: 55-62.

Peng X., YeL L., Wang CH., Zhou H., Sun B. 2011. Temperature and duration dependent rice straw-derived biochar: Characteristics and its effects on soil properties of anultisolin southern china. Soil Tillage Research, 112: 159-166.

Praba ML., Cairns JE., Babu RC., Lafitte HR. 2009. Identification of physiological traits underlying cultivar differences in drought tolerance in rice and wheat. J. Agron. Crop Sci, 195: 30-46.
Rizwan M., Qayyum M., Ali S., Ok Y., Ibrahim M., Riaz M., Arif M., Hafeez F., AlWabel., Shahzad A. 2017. Biochar soil amendment on alleviation of drought and salt stress in plants: a critical review. Environmental Science and Pollution Response. doi:10.1007/s11356-017-8904$\mathrm{x}$

Rohbakhsh H. 2013. Alleviating adverse effects of water stress on growth and yield of forage sorghum by potassium application. Advances Environ Biol, 7(1): 40-46.

Thomas SC., Frye S., Gale N., Garmon M., Launchbury R., Winsborough C. 2013. Biochar mitigates negative effects of salt additions on two herbaceous plant species. Journal of Environmental Management, 129:62-68.

Uzoma KC.,Inoue M., Andry H., Fujimaki H., Zahoor A.,Nishihara E. 2011. Effect of cow manure biochar on maize productivity under sandy soil condition. Soil Use Manage, 27:205-212.

WPSA, report. 2013. Commercial broiler growth. Report on Maize value Chain in Northern Char Areas in Bangladesh. Prepared by OXFAM, Dhaka, Bangladesh. 